\title{
Evaluation of $\beta$-Galactosidase Activity in Tissue in the Presence of Blood
}

\author{
Jaroslav Pelisek Sorin Armeanu Sigrid Nikol \\ Medical Clinic I, Klinikum Grosshadern, Munich, Germany
}

\section{Key Words}

Hemoglobin · $\beta$-Galactosidase - Gene transfer • Primary smooth muscle cells $\cdot$ Pig arteries

\begin{abstract}
The reporter gene for $\beta$-galactosidase is frequently used to determine the efficiency of gene transfer in arteries. However, blood is often present in arterial explants and may compromise the results by the presence of hemoglobin. The light absorption of hemoglobin is similar to the absorption of several colorimetric products of the commonly used $\beta$-galactosidase substrates, including $o$ nitrophenyl- $\beta$ - $D$-galactopyranoside (ONPG) and chlorophenol red galactopyranoside (CPRG). This may result in false-positive measurements of $\beta$-galactosidase enzyme activity. The aim of this investigation was to determine the most appropriate method for quantification of $\beta$-galactosidase activity in the presence of blood. Colorimetric substrates (ONPG, CPRG) or the chemiluminescent Galacton-Plus substrate were used, and light absorption was measured at different concentrations of erythrocyte extract. Among the $\beta$-galactosidase substrates tested, CPRG was the most appropriate, allowing detection of enzyme activity at concentrations as low as $0.05 \mathrm{mU}$, independent of blood contamination. Addition of reduc-
\end{abstract}

\begin{tabular}{ll}
\hline KARGER & ( 2000 S. Karger AG, Basel \\
Fax +4161306 1234 & \\
$\begin{array}{l}\text { E-Mail karger@karger.ch } \\
\text { www.karger.com }\end{array}$ & $\begin{array}{l}\text { Accessible online at: } \\
\text { www.karger.com/journals/jvr }\end{array}$
\end{tabular}

er stabilized enzyme activity for at least $5 \mathrm{~h}$. Endogenous $\beta$-galactosidase activity was evaluated and used to correct results. CPRG substrate, in combination with the reducer agent mercaptoethanol, was found to be the optimal reagent for quantifying $\beta$-galactosidase activity in the presence of blood after nonviral in vivo reporter gene transfection, even with a relatively low transfer efficiency.

Copyright $@ 2000$ S. Karger AG, Basel

\section{Introduction}

The reporter gene $\beta$-galactosidase is frequently used to determine transfection efficiencies in cell cultures or tissues. The administration of the gene for $\beta$-galactosidase and the detection methods to assess the protein product are relatively simple and cost-effective. Transfected cells may be identified in situ by blue staining, which results when the substrate 5-bromo-4-chloro-3-indolyl- $\beta-D$-galactopyranoside is converted by the expressed $\beta$-galactosidase into 5-bromo-4-chloro-3-hydroxyindol. For quantitative evaluations, $\beta$-galactosidase expression is usually analyzed using colorimetric assays, which measure enzyme activity. Several substrates are available for colorimetric assays, including $o$-nitrophenyl- $\beta$ - $D$-galactopyra-

Dr. Sigrid Nikol

Medical Department I, Klinikum Grosshadern

Marchioninistrasse 15

D-81377 Munich (Germany)

Tel. +49 897095 3166, Fax +49 897095 6166, E-Mail s-nikol@gmx.de 
noside (ONPG [1]) and chlorophenol red galactopyranoside (CPRG [2, 3]). In addition, several highly sensitive chemiluminescence assays are now available for measuring light emission, for example Galacton-Light ${ }^{\mathrm{TM}}$ or Galacton-Light Plus ${ }^{\mathrm{TM}}[4,5]$ (Tropix, Bedford, Mass., USA).

Blood is frequently present in tissue samples, particularly when tissues derive from arteries or other blood vessels. Hemoglobin, found in erythrocytes and blood, has an absorption spectrum between 400 and $600 \mathrm{~nm}$, with a maximum between 520 and $580 \mathrm{~nm}$. Hence, the light absorption of hemoglobin is similar to the absorption of $\beta$-galactosidase products, which results from $400-430 \mathrm{~nm}$ for ONPG and from $540-590 \mathrm{~nm}$ for CPRG. This may result in false-positive measurements of $\beta$-galactosidase enzyme activity. For vascular nonviral gene transfer experiments in vivo, transfer efficiencies are commonly less than $1 \%$. Furthermore, each tissue sample may contain unpredictable amounts of blood. Therefore, quantitative analysis using these substrates might not be interpretable or reproducible.

In this paper, a photometric method that allows accurate quantification of $\beta$-galactosidase activity, even in the presence of blood contamination, is described in transfected primary cultures of porcine smooth muscle cells (SMCs) and transfected porcine arteries.

\section{Methods}

\section{Cell Culture}

Primary cultures of porcine SMCs were isolated from explants of pig arteries and cultured in medium (equal volumes of HAM, Biochrom KG, Berlin, Germany and Waymouth, Gibco BRL, Eggenstein, Germany) with $10 \%$ fetal calf serum, $4 \mathrm{mM}$ glutamine, $100 \mathrm{U}$ penicillin, $100 \mu \mathrm{g} / \mathrm{ml}$ streptomycin and $2.5 \mathrm{mg} / \mathrm{ml}$ amphotericin B as previously described [6]. SMCs from the first 4 passages were used.

\section{Tissue Samples}

Fresh tissue samples taken from various organs obtained from normal pigs were analyzed for endogenous $\beta$-galactosidase. Tissue specimens were divided, rapidly snap-frozen in liquid nitrogen and stored at $-80^{\circ} \mathrm{C}$. Samples were later homogenized and resuspended in $200 \mu \mathrm{l}$ of lysis buffer ( $100 \mathrm{~m} M$ potassium phosphate, $\mathrm{pH} 7.8,0.2 \%$ Triton X-100); mercaptoethanol $(100 \mathrm{~m} M)$ was added fresh prior to use. Samples were centrifuged at 15,000 rpm for $15 \mathrm{~min}$ and the supernatant (protein extract) was used for further experiments.

\section{Optical Density Measurement}

Optical density was measured in erythrocyte extract supplemented with bovine serum albumin or SMC extract. Erythrocyte extract was prepared by centrifugation of human blood at 5,000 rpm for $10 \mathrm{~min}$. The lowest layer, containing erythrocytes, was mixed with lysis buffer $(1: 1, \mathrm{v} / \mathrm{v})$ and the protein concentration was deter- mined using the bicinchoninic acid protein assay (Pierce, St. Augustin, Germany). SMC protein extract was prepared by trypsinization of cell cultures, centrifugation and resuspension in $100 \mu \mathrm{l}$ of lysis buffer. Optical density was quantified at the wavelengths used for quantitative $\beta$-galactosidase assays. Absorption was measured at $405 \mathrm{~nm}$ for ONPG and $540 \mathrm{~nm}$ for CPRG using samples of 10$100 \mu \mathrm{g}$ protein from erythrocyte extracts made up of $100 \mu \mathrm{g}$ of total protein with either bovine serum albumin or SMC protein extract to exclude any influence of other cellular proteins.

\section{Measurement Using Colorimetric Substrates}

For quantification of $\beta$-galactosidase gene expression, samples were prepared on 96-well plates in duplicates. Extracts containing $100 \mu \mathrm{g}$ protein contaminated with blood were diluted in $50 \mu \mathrm{l}$ lysis buffer. The two colorimetric substrates were CPRG and ONPG. In the first part of the experiment, carried out without substrate, $150 \mu \mathrm{l}$ of HBSS (Hanks' balanced salt solution) were added; in the second part of the experiment, the substrate was used instead. CPRG: $150 \mu \mathrm{l}$ of CPRG substrate ( $1 \mathrm{mg} / \mathrm{ml}$ in HBSS) were added; at $30 \mathrm{~min}, 1,2,3$ and $4 \mathrm{~h}$ following the addition of HBSS or CPRG, consecutive measurements of the optical density at $540 \mathrm{~nm}$ were performed. ONPG: $150 \mu 1$ assay buffer containing the ONPG substrate, prepared according to the manufacturer's protocol (Promega, Munich, Germany), were added and incubated at $37^{\circ} \mathrm{C}$ for $30-120 \mathrm{~min}$. The optical density was measured at $405 \mathrm{~nm}$. The reference wavelength for the ELISA reader (Titertek Multiscan MCC/340, EFLAB, Helsinki, Finland) was $690 \mathrm{~nm}$. Activity was calculated using known enzyme activity of $\beta$-galactosidase (Promega) and corrected for any activity from nontransfected SMCs.

\section{Measurement Using Chemiluminescent Substrate}

Galacton-Plus substrate (Roche, Ingelheim, Germany) was diluted to make reaction buffer as described according to the manufacturer's recommendations. Aliquots of $2-20 \mu \mathrm{l}$ of the $100 \mu \mathrm{g}$ protein extract were supplemented to a total volume of $20 \mu 1$ with lysis buffer. Reaction buffer $(200 \mu \mathrm{l})$ was added to a luminometer cuvette, gently mixed with the protein extract and incubated at room temperature for $60 \mathrm{~min}$. The cuvette was placed in a luminometer (Lumat LB9507, Berthold, Pforzheim, Germany), and $300 \mu \mathrm{l}$ of light emission accelerator were injected. Five seconds following this injection, light emission was quantified for $10 \mathrm{~s}$. Measurements were obtained in the presence or absence of erythrocyte extract.

Calculation of $\beta$-Galactosidase Activity in the Presence of Blood

Erythrocyte extract samples of 10-100 $\mu \mathrm{g}$ were supplemented with SMC protein extract to $100 \mu \mathrm{g}$ protein. Optical densities at $540 \mathrm{~nm}$ were determined for each concentration of blood. Results were illustrated in a graph (fig. 1a). The optical density of the bloodcontaminated samples $\left(\mathrm{OD}_{\text {blood }}\right)$ was measured without substrate and corrected for background absorption without blood. At the optical density of a sample without substrate $\left(\mathrm{OD}_{\text {blood }}\right)$, the blood content (BC) in the sample was determined on the $\mathrm{x}$-axis. The measured optical density of the same sample with $C P R G$ substrate $\left(\mathrm{OD}_{\text {sample }}\right)$ was then corrected by subtracting $\mathrm{OD}_{\text {blood. }}$ This value was divided by $(1-\mathrm{BC})$ to obtain the optical density of the sample corrected for blood contamination $\left(\mathrm{OD}_{\beta \text {-gal }}\right)$ for $100 \mu \mathrm{g}$ tissue protein:

$$
\mathrm{OD}_{\beta \text {-gal }}=\left(\mathrm{OD}_{\text {sample }}-\mathrm{OD}_{\text {blood }}\right) /(1-\mathrm{BC}) \text {, }
$$

where $\mathrm{OD}_{\beta \text {-gal }}=$ calculated specific optical density of the transfected $\beta$-galactosidase corrected for blood contamination and for $100 \mu \mathrm{g}$ 
total protein; $\mathrm{OD}_{\text {sample }}=$ measured optical density of the blood-containing sample with substrate; $\mathrm{OD}_{\text {blood }}=$ measured optical density of blood-containing sample without substrate, corrected for background absorption; $(1-\mathrm{BC})=$ factor correcting the calculated optical density of $\beta$-galactosidase for blood content per $100 \mu \mathrm{g}$ total protein.

The optical density calculated as above was extrapolated on the $x$-axis using the $\beta$-galactosidase standard curve. This gave the specific $\beta$-galactosidase activity (fig. 1b). This value was further corrected by subtracting endogenous $\beta$-galactosidase activity.

\section{Endogenous $\beta$-Galactosidase Activity}

The endogenous $\beta$-galactosidase enzyme activity was determined using $100 \mu \mathrm{g}$ of protein extract from porcine SMCs in primary culture and from organs of nontransfected pigs. Enzyme activities were measured and corrected for blood content as described above.

\section{Transfection of Cell Cultures}

To test the analytical method, primary cell cultures of porcine SMCs were transfected with the gene for $\beta$-galactosidase. Porcine SMCs were seeded into 6-well plates $48 \mathrm{~h}$ before transfection (100,000-200,000 cells/well). The cationic lipids DOCSPER [1,3dioleoyloxy-2-( $\mathrm{N}^{5}$-carbamoyl-spermine)-propane] [7] or LipofectAMINE (Gibco, Eggenstein, Germany) complexed with the plasmid pCMV $\beta$ (Clontech, Heidelberg, Germany) were used for gene transfer. The pCMV $\beta$ plasmid $(1 \mu \mathrm{g})$ and the liposomes $(5 \mu \mathrm{g})$ were separately each diluted in $100 \mu \mathrm{l}$ of serum-free medium, then mixed and incubated for $30 \mathrm{~min}$ at room temperature. SMCs were washed twice with phosphate-buffered saline (PBS) and the wash buffer was displaced with $800 \mu \mathrm{l}$ serum-free medium. The transfection complex was added drop-wise to the cells. After $4 \mathrm{~h}$ incubation time at $37^{\circ} \mathrm{C}$ in $5 \% \mathrm{CO}_{2}$, the medium was replaced with fresh medium including $10 \%$ fetal calf serum.

For the analysis of $\beta$-galactosidase activity, cells were washed with PBS $48 \mathrm{~h}$ following transfection and trypsinized for 5 min with $0.25 \%$ trypsin/PBS. Cell numbers were determined with a particle counter (CASY 1, Schärfe System, Reutlingen, Germany). Cells were suspended in $100 \mu \mathrm{l}$ lysis buffer, centrifuged at $4{ }^{\circ} \mathrm{C}$ and the supernatant was used for further experiments.

\section{Transfection of Pig Arteries in vivo}

Pig iliac arteries were transfected with $\mathrm{pCMV} \beta$, and animals were sacrificed after 1 week. The protocol has previously been published [6]. All animal procedures were approved by the Animal Care and Use Review Committee of the University of Marseille according to French guidelines. Study animals were Pietrain pigs (average weight $35 \mathrm{~kg}$ at the initial procedure; $\mathrm{n}=12$ ). Anesthesia and balloon angioplasty in iliac arteries were performed as previously described [6]. Balloon catheters were introduced via 6-french intra-arterial sheaths into femoral arteries and balloons of $4 \mathrm{~cm}$ length were inflated for 3 times at 8 atm for $1 \mathrm{~min}$.

After deflation and withdrawal of the balloon in each femoral artery of study animals $30 \mu \mathrm{g}$ plasmid DNA with $300 \mu \mathrm{g}$ DOCSPER in $2 \mathrm{ml}$ serum-free DMEM were deposited into two experimental segments using a needle injection catheter (BMT, Oberpfaffenhofen, Germany) as described [6]. Sacrifice took place 7 days after transfection, using the same anesthetic protocol, including orotracheal intubation and mechanical ventilation. Blood samples, noninjured carotid arteries and skeletal muscle adjacent to the treated vessel and organs (liver, lung, spleen, heart, small intestine and kidney) were removed before arteries treated with plasmids using RNase-free

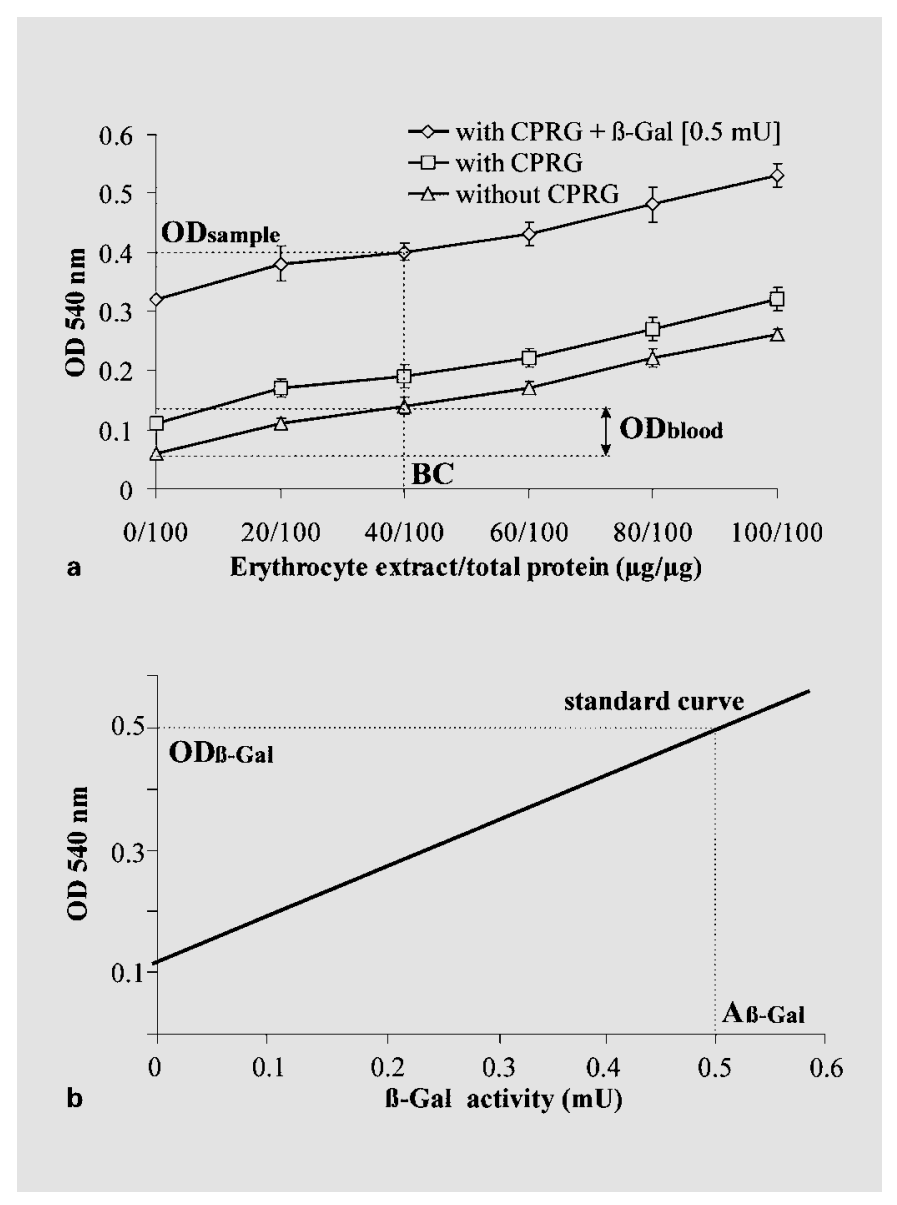

Fig. 1. Graph to determine specific $\beta$-galactosidase activity of bloodcontaining samples. a Optical density of samples containing different erythrocyte extract concentrations in the presence $(\square)$ and absence $(\triangle)$ of CPRG substrate and also with CPRG and a known $\beta$-galactosidase concentration $(0.5 \mathrm{mU}, \diamond)$. All curves show approximately linear dependence and are shifted in parallel. From this graph the optical density of the sample containing blood $\left(\mathrm{OD}_{\text {sample }}\right)$, the optical density of the blood contamination $\left(\mathrm{OD}_{\text {blood }}\right)$ and the amount of blood in the sample (BC) can be determined. b $\beta$-Galactosidase standard curve, from which the specific enzyme activity $\left(\mathrm{A}_{\beta \text {-gal }}\right)$ can be extrapolated after the specific optical density $\left(\mathrm{OD}_{\beta \text {-gal }}\right)$ has been calculated. Data are means \pm SD from minimally 3 identical experiments with determination performed at least in triplicate.

instruments were explanted. Vessels were then cross-sectioned starting at the proximal site into 0.5 -cm-thick segments and each second segment was embedded in OCT compound (Miles Scientific, Elkhart, Ind., USA); the other tissue samples were snap-frozen.

\section{Analysis of the $\beta$-Galactosidase $m R N A$}

Snap-frozen tissue was homogenized in liquid nitrogen and RNA was prepared with RNAzol B reagent (CINNA/MRC, Cincinnati, Ohio, USA). Total RNA (1-5 $\mu \mathrm{g})$ was reverse transcribed employing the T-Primed First-Strand cDNA Synthesis Ready To Go Kit (Phar- 
macia). A PCR was performed as previously described [6]. The quality of transcribed RNA was shown by amplification of the 5'-end of the GAPDH gene transcript (GAPDH L1: 5'-CGTCTTCACCACCATGGAAGAAGGC-3'/GAPDH R2: 5'-AAGGCCATGCCAGTGAGCTTCCC-3', 398 bp). For the detection of the transfected plasmids the following primers were used: $\beta$-galactosidase b-gal $\mathrm{L}^{\prime}$ : 5'-GCATCATCCTCTGCATGGTCAG-3' and b-gal R1: 5'-AAACCGCAAGACTGTTACCCATCG-3' (572 bp). Amplified DNA fragments were analyzed by electrophoresis on $1.5 \%$ agarose gels.

Statistical Analysis

All values are expressed as means \pm standard error (SD) of 3 or 4 experiments for each condition. One-way ANOVA was used for comparison of differences among the groups (SPSS Inc., Chicago, Ill., USA). The statistical significance was defined as $\mathrm{p}<0.05$.

\section{Results}

\section{Optical Density of Erythrocyte Extracts}

The optical densities of different erythrocyte extract concentrations (ranging from 10 to $100 \mu \mathrm{g}$ ) supplemented with bovine serum albumin or SMC protein extract were determined. The optical densities measured in erythrocyte extracts at the different concentrations were independent of the presence of supplemented bovine serum albumin or SMC protein (data not shown).

\section{Measurement Using Colorimetric Substrates}

The optical densities of samples with different erythrocyte extract concentrations supplemented with protein extract of SMCs were measured in the presence or absence of the $\beta$-galactosidase substrates CRPG or ONPG. Without substrate, the absorption was directly proportional to the amount of erythrocyte extract applied, giving rise to a linear curve (fig. 1). If CPRG substrate was added to samples with the same concentrations of erythrocyte extract, a second linear curve shifted parallel to the curve without substrate appeared (fig. 1a). Addition of CPRG and a known $\beta$-galactosidase concentration $(0.5 \mathrm{mU})$ resulted in further parallel shifting of the curve on the yaxis (fig. 1a). In contrast, addition of ONPG showed no significant difference between curves with or without substrate (fig. 2). The curve grades were steeper compared with curves using CPRG substrate. Addition of $\beta$-galactosidase with $1.0 \mathrm{mU}$ activity did not show any significant shift of the curve. First higher $\beta$-galactosidase enzyme activity $(5.0 \mathrm{mU})$ resulted in an almost parallel shift of the curve. Without blood contamination, the use of the ONPG substrate resulted in values proportional to those obtained using the CPRG substrate. However, overall, the use of ONPG demonstrated 20\% lower $\beta$-galactosi-

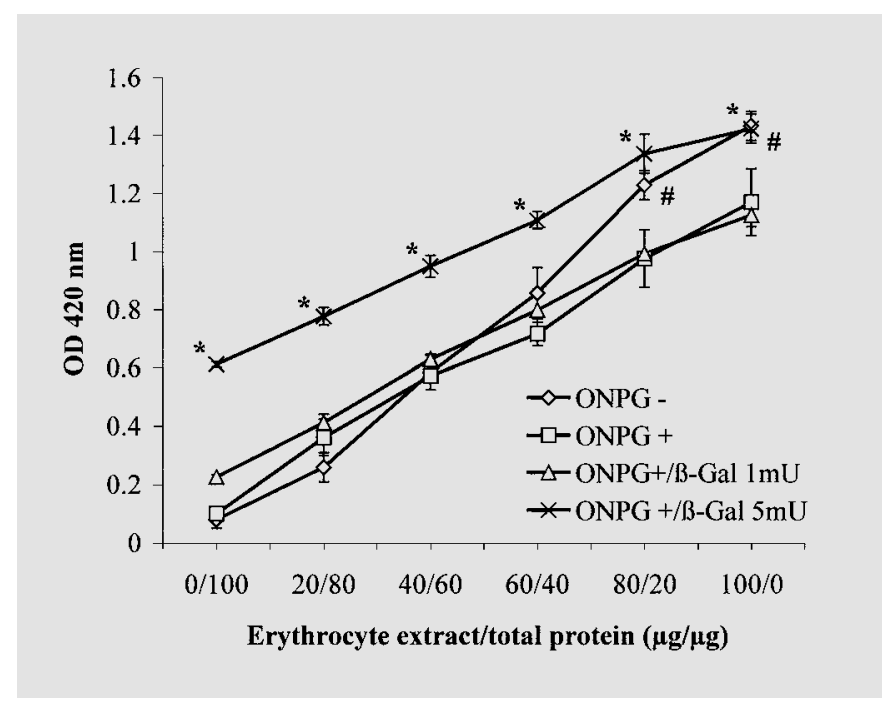

Fig. 2. Optical density of different erythrocyte extract concentrations with $(\square)$ and without $(\diamond)$ ONPG substrate and also with a known $\beta$-galactosidase concentration $(\triangle=1.0 \mathrm{mU}, x=5 \mathrm{mU})$. There was no parallel shift observed between the curves with and without substrate with increasing concentrations of the erythrocyte extract. Similar results were obtained with $1.0 \mathrm{mU}$ of $\beta$-galactosidase enzyme activity. The shift of the curve was seen first at $5.0 \mathrm{mU}$. Values are means $\pm \mathrm{SD} .{ }^{*} \mathrm{p}<0.05$ for $\mathrm{ONPG}+/ \beta-\mathrm{Gal} 5 \mathrm{mU}$ versus ONPG+; \# $\mathrm{p}<0.05$ for ONPG- versus ONPG+.

dase activities compared with the use of the CPRG substrate for measurement.

\section{Measurement Using Chemiluminescent Substrate}

The Galacton-Plus substrate also demonstrated changes in light emission in the presence of blood. Overall, luminescence values recorded using this substrate for measurement of $\beta$-galactosidase activity were $20-30 \%$ lower when erythrocyte extract was added, independently of the erythrocyte extract concentration. There was no correlation between increasing erythrocyte extract concentrations and lowering of luminescence measured (fig. 3).

\section{Calculation of $\beta$-Galactosidase Activity in the Presence of Blood}

Experiments using the CRPG substrate to measure $\beta$ galactosidase activity in SMC extracts were carried out with known $\beta$-galactosidase enzyme concentrations $(0.05$, 0.10 and $0.50 \mathrm{mU}$ ) with and without blood contamination. Optical densities of the samples and resulting $\beta$-galactosidase activities were calculated as described in the Methods section and are demonstrated in figure 1. Blood- 


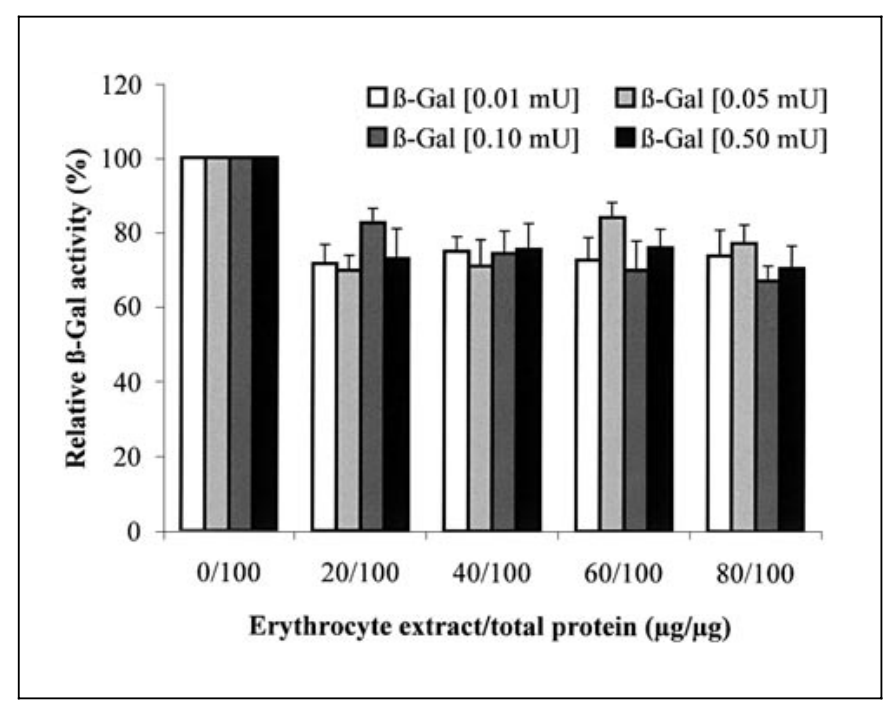

Fig. 3. Influence of blood contamination on the results using the chemiluminescent substrate Galacton-Plus. The Galacton-Plus substrate also demonstrated changes in light emission in the presence of blood. The light emission was $20-30 \%$ lower comparing with samples without blood contamination independent of erythrocyte extract concentrations. Values are given as means \pm SD. A significance of $\mathrm{p}<0.05$ was found for $0 / 100$ (erythrocyte extract/whole protein, $\mu \mathrm{g}$ / $\mu \mathrm{g})$ versus all other groups $(20 / 100,40 / 100,60 / 100,80 / 100)$.

contaminated samples with known $\beta$-galactosidase concentrations were compared with samples containing the same $\beta$-galactosidase amount without the presence of blood. Results confirmed the accuracy of the method for correcting for the presence of blood (fig. 4). Accurate values were obtained at concentrations of $\beta$-galactosidase of more than $0.05 \mathrm{mU}$. However, for samples with concentrations of $\beta$-galactosidase of $0.05 \mathrm{mU}$ or lower, there were deviations of up to $40 \%$ of enzyme activity also with correction. $\beta$-Galactosidase activities obtained without correction for blood contamination yielded values 2-4 times higher than those which were corrected (fig. 4).

\section{Stabilization of $\beta$-Galactosidase Activity Using \\ Reducing Agents}

For these experiments protein extracts were made using lysis buffer without mercaptoethanol. $\beta$-Galactosidase enzyme activities in samples without blood contamination remained stable for at least 5-6 $\mathrm{h}$ also in the absence of mercaptoethanol. Blood-containing samples without reducer demonstrated their highest $\beta$-galactosidase activity $30 \mathrm{~min}$ following addition of the substrate. This decreased rapidly over time (fig. 5a,b). Samples with

$\beta$-Galactosidase Activity in the Presence of Blood

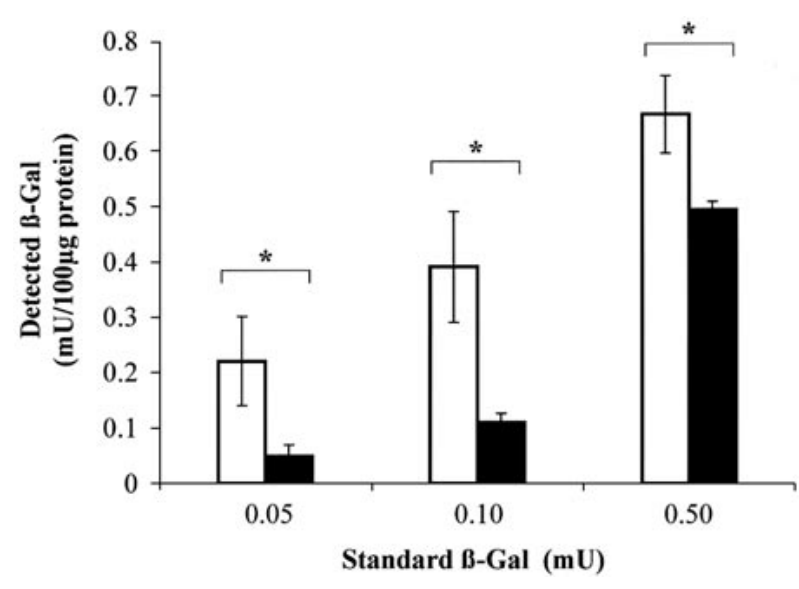

Fig. 4. Enzyme activity measured at known $\beta$-galactosidase concentrations $(0.05,0.10$ and $0.50 \mathrm{mU})$ in the presence of blood contamination. $\square=\beta$-Galactosidase enzyme activity values without correction; $\mathbf{\square}=$ activity values using the described method to correct for presence of blood (see text). Duplicates or triplicates of $50 \mu \mathrm{g} \mathrm{SMC}$ extract, $50 \mu \mathrm{g}$ erythrocyte extract and a defined concentration of $\beta$ galactosidase were mixed to a total of $100 \mu \mathrm{g}$ protein. Uncorrected values resulted in 2-4 times higher enzyme activity recorded, compared with corrected values. Calculated $\beta$-galactosidase activities yielded values that correlated with values expected $(* p<0.05)$.

blood contamination but without reducer demonstrated consistently higher enzyme activities than the known enzyme activity of the $\beta$-galactosidase added to the sample. In contrast, values for calculated $\beta$-galactosidase activity from blood-contaminated samples treated with the reducing agent mercaptoethanol $(100 \mathrm{~m} M$, included in the lysis buffer) remained stable, correlating well with the known enzyme activity of the $\beta$-galactosidase present in the sample (fig. 6).

\section{Endogenous $\beta$-Galactosidase Activity}

The endogenous $\beta$-galactosidase activity in porcine SMCs grown in primary cultures and in various porcine organs from 5 animals was determined and corrected for blood content (fig. 7). Endogenous $\beta$-galactosidase activities calculated without correction for blood contamination demonstrated markedly higher values than the samples corrected for blood content. $\beta$-Galactosidase activity was dependent on the amount of blood in the sample (data not shown). In extracts from porcine SMCs in primary culture, the endogenous activity for $\beta$-galactosidase was not detectable. Iliac arteries, carotid arteries and heart and lung tissue demonstrated endogenous $\beta$-galacto- 

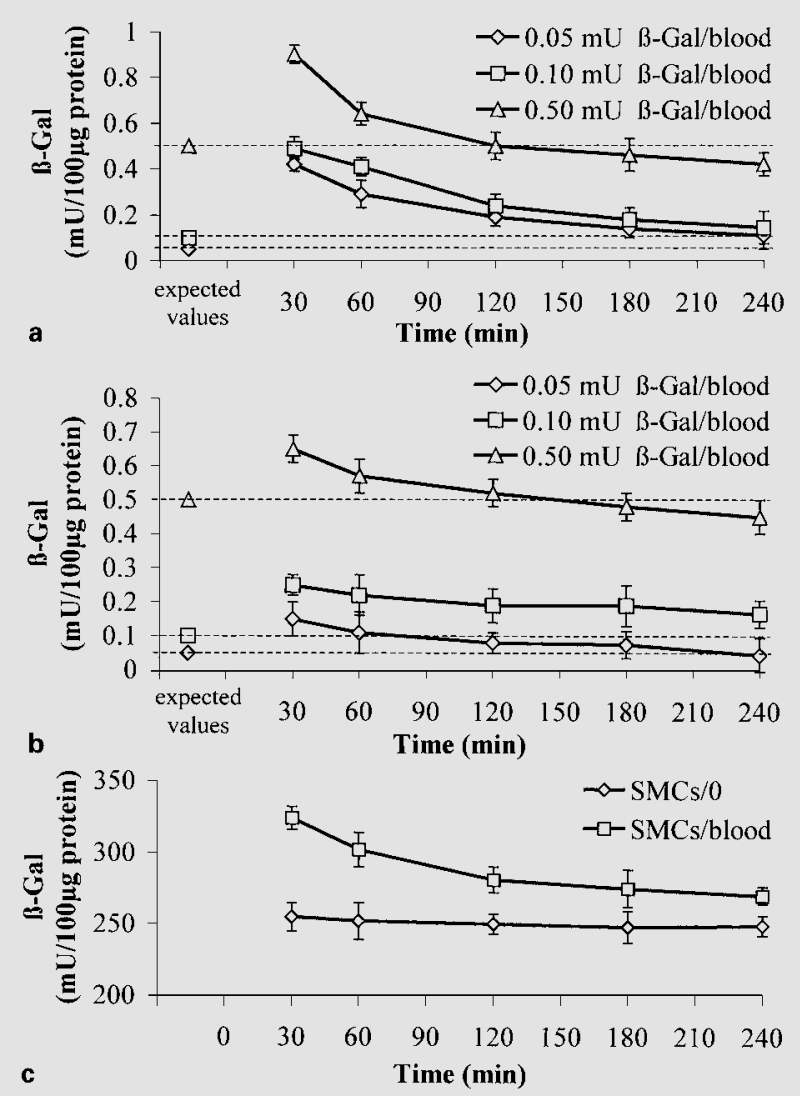

Fig. 5. Time-dependent $\beta$-galactosidase activity of blood-contaminated samples in the absence of reducer compared with expected values. a SMC extract mixed with $50 \mu$ l erythrocyte extract to a total protein concentration of $100 \mu \mathrm{g}$ and known $\beta$-galactosidase enzyme activity $(0.05,0.10,0.50 \mathrm{mU})$. b Measurement of arterial tissue samples (carotid artery) contaminated with blood and known $\beta$-galactosidase enzyme activity. Both $\mathbf{a}$ and $\mathbf{b}$ demonstrated in the absence of reducer decreasing $\beta$-galactosidase enzyme activity progressively over time. c Transfection of SMCs and addition of erythrocyte extract to one part of the transfected samples. Without blood contamination, there was stable enzyme activity throughout the measurements. In contrast, transfected SMCs containing erythrocyte extract without reducer treated similarly to $\mathbf{a}$ and $\mathbf{b}$ resulted also in decreasing $\beta$-galactosidase activity over the measurement period. Values represent means $\pm \mathrm{SD}$.

sidase activity of between 0.1 and $0.2 \mathrm{mU}$ (iliac arteries $0.13 \pm 0.08 \mathrm{mU}$, carotid arteries $0.2 \pm 0.05 \mathrm{mU}$, heart tissues $0.14 \pm 0.04 \mathrm{mU}$, lung tissues $0.2 \pm 0.06 \mathrm{mU})$. The highest endogenous activity was obtained in kidney (4.3 $\pm 0.8 \mathrm{mU})$, followed by liver $(1.7 \pm 0.17 \mathrm{mU})$, intestinal tissue $(1.5 \pm 0.08 \mathrm{mU})$ and lymph nodes $(0.3 \pm$ $0.6 \mathrm{mU})$.
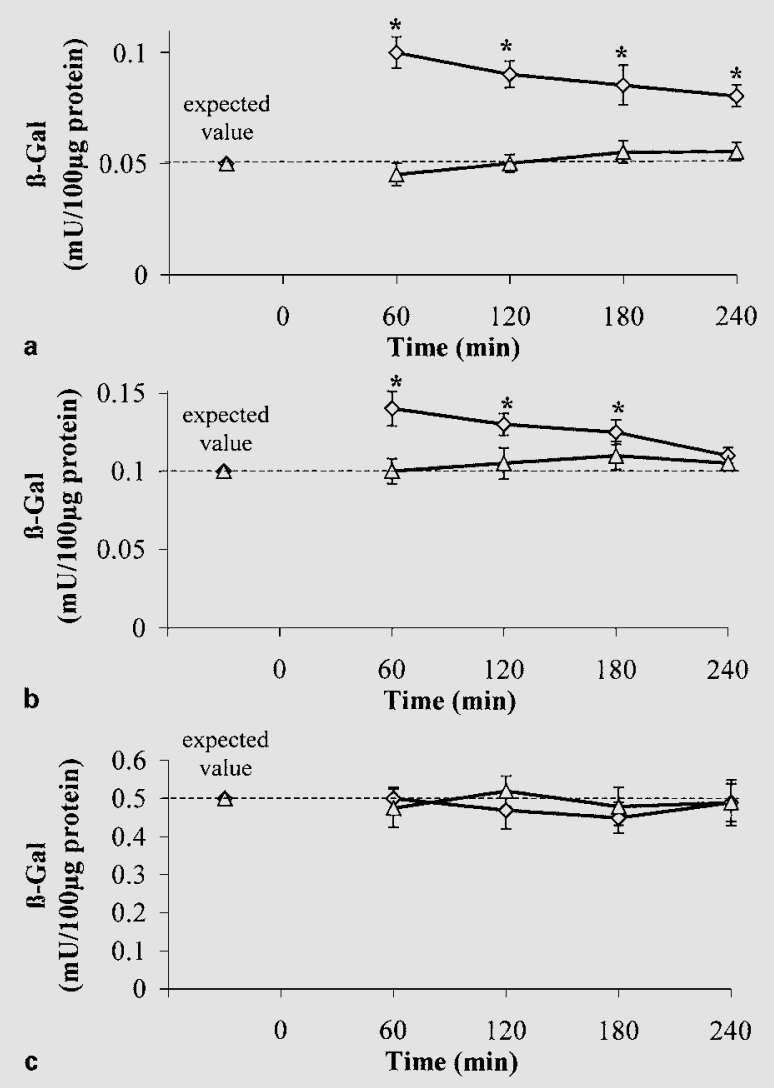

Fig. 6. Influence of reducing agents on the stability of $\beta$-galactosidase activity measurement in the presence of blood contamination $(\diamond=$ without reducer, $\square=$ with mercaptoethanol). SMC extract was mixed with $50 \mu \mathrm{g}$ of erythrocyte extract to a total protein content of $100 \mu \mathrm{g}$ and known concentrations of $\beta$-galactosidase were added: $0.05 \mathrm{mU}$ (a), $0.10 \mathrm{mU}$ (b) and $0.5 \mathrm{mU}$ (c). Finally, mercaptoethanol $(100 \mathrm{mM})$ was supplemented. The reducing agent was able to stabilize the enzyme activity during the whole measurement. Data are means \pm $\mathrm{SD}$ from 3 experiments. Significant differences to the expected activity were marked $(* \mathrm{p}<0.05)$.

\section{B-Galactosidase Activity in Transfected Cell Cultures}

Transfection of SMCs in primary culture was performed using the pCMV $\beta$ vector containing the $\beta$-galactosidase gene. Measurement of the $\beta$-galactosidase enzyme activity in cells without blood contamination using the CPRG substrate demonstrated consistency in the values measured over a 4-hour time period after substrate addition. In contrast, cultured SMCs supplemented with 10-100 $\mu$ g protein of erythrocyte extract showed markedly increased values, which were 10-30\% higher (fig. 5c). 


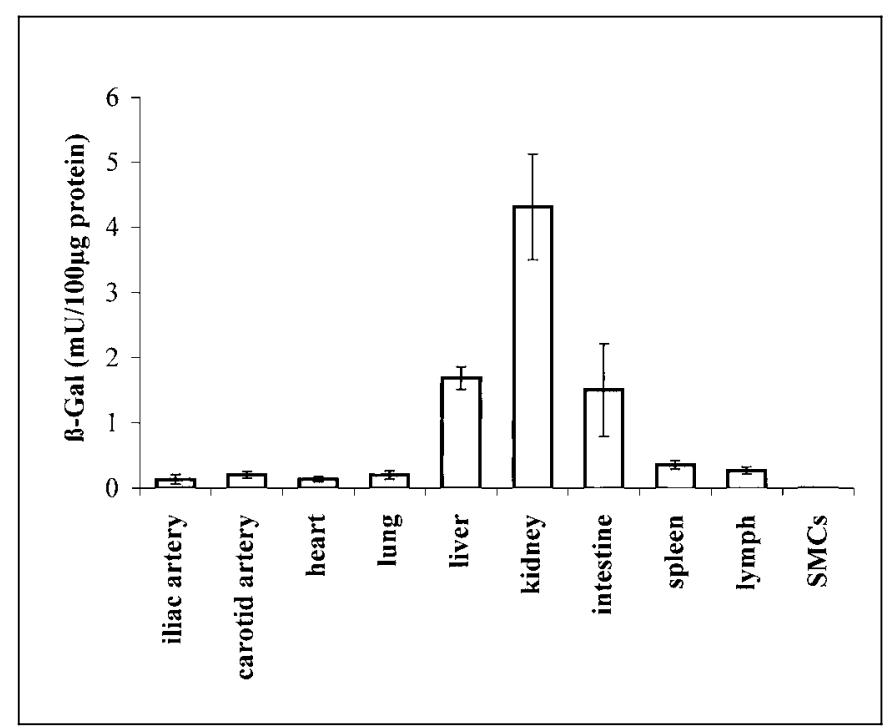

Fig. 7. Endogenous $\beta$-galactosidase activity of tissue extracts from various porcine organs. The organs analyzed (arteries, heart, lung, liver, kidney, intestine, spleen and lymph nodes) were explanted from 5 animals and proteins were extracted from specimens. From each tissue $100 \mu \mathrm{g}$ of protein was used to determine the $\beta$-galactosidase enzyme activity. Iliac arteries, carotid arteries and heart and lung tissue showed relatively low values between 0.1 and $0.2 \mathrm{mU}$ (iliac arteries $0.13 \pm 0.08 \mathrm{mU}$, carotid arteries $0.2 \pm 0.05 \mathrm{mU}$, heart tissue $0.14 \pm 0.04 \mathrm{mU}$, lung tissue $0.2 \pm 0.06 \mathrm{mU})$. Spleen and lymph nodes achieved $0.2 \pm 0.05$ and $0.3 \pm 0.06 \mathrm{mU}$. The highest endogenous $\beta$-galactosidase activity was demonstrated by intestine $(1.5 \pm 0.08 \mathrm{mU})$, liver $(1.7 \pm 0.17 \mathrm{mU})$ and kidney $(4.3 \pm 0.8 \mathrm{mU})$. The values are means \pm SD from 5 independent samples performed in triplicate.

Calculated values decreased incrementally over time. Results were consistent with the previous experiments conducted with extracts of SMC protein and addition of known $\beta$-galactosidase concentrations (fig. 4). Endogenous $\beta$-galactosidase activity was not detectable in cultures of SMCs, and no further correction of values was necessary.

\section{$\beta$-Galactosidase Activity in Transfected Tissues}

Following a protocol previously described [6], transfected pig iliac arteries were analyzed for expression of $\beta$-galactosidase gene using RT-PCR and $\beta$-galactosidase enzyme activity measurements. Results are summarized in figure 8 . Uncorrected $\beta$-galactosidase activity values were $0.5-5$ times higher than the results corrected according to the procedure described in this paper (fig. 8a). Uncorrected $\beta$-galactosidase activities were too high or demonstrated also false-positive results (fig. 8a, segment

$\beta$-Galactosidase Activity in the Presence of Blood

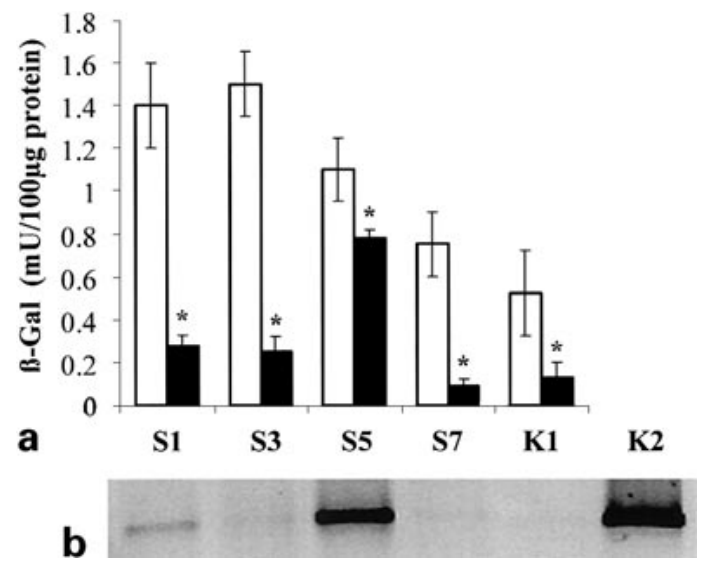

Fig. 8. Transfection experiments in vivo: $\beta$-galactosidase enzyme activity (a) and $\beta$-galactosidase gene expression (b). S1-S7 = Transfected arterial segments; $\mathrm{K} 1=$ nontransfected tissue; $\mathrm{K} 2=\mathrm{pCMV} \beta$. The uncorrected $\beta$-galactosidase enzyme activity $(\square)$ demonstrated significantly $(* \mathrm{p}<0.05)$ higher and even false-positive enzyme activities compared with the corrected results $(\boldsymbol{\square})$. $\beta$-Galactosidase activity values corrected for the blood content correlated well with $\beta$-galactosidase gene expression using RT-PCR. Data are means \pm SD performed in triplicate.

S7). In contrast, $\beta$-galactosidase enzyme activities corrected for blood content correlated well with the results obtained by RT-PCR (fig. 8b).

\section{Discussion}

The hemoglobin within blood may significantly compromise results obtained when $\beta$-galactosidase activity is measured in arterial tissue samples. This is particularly true when transfection efficiencies are low. This applies to many cardiovascular gene transfer experiments performed on arteries in vivo. In this paper, the influence of the presence of blood contamination on $\beta$-galactosidase analyses was evaluated and a method for the correct determination of enzymatic activity was established. This method allows correction of errors resulting from the presence of blood.

Addition of protein extract from BSA or from cultured SMCs to different erythrocyte extract concentrations did not result in any changes in optical density measured. It can be concluded that other cellular proteins that may be 
contaminating do not influence the absorption properties of blood-containing solutions.

Of the $\beta$-galactosidase substrates tested, CPRG appeared to be optimal for the determination of $\beta$-galactosidase activity in the presence of erythrocyte extract. Using CPRG, a parallel shift of the curves for the optical densities of samples with and without substrate was observed. The parallel shift may be explained by the specific absorption of CPRG, which evenly increases each value for optical densities obtained. Thus, the sample did not influence the absorption of the substrate. The parallel shift allows the actual activity to be calculated.

In samples with blood contamination, the concentration of erythrocytes may be obtained using the formula proposed. The use of the formula was demonstrated to be accurate by carrying out experiments using samples with a known $\beta$-galactosidase content and blood contamination. The specific $\beta$-galactosidase activity of samples obtained using the CPRG substrate allowed measurements of enzyme activities to be determined down to levels as low as $0.05 \mathrm{mU}$, even in the presence of blood. Blood-contaminated controls with a known $\beta$-galactosidase content analyzed using photometric $\beta$-galactosidase methods without the calculation procedure resulted in values, which were too high or a false-positive enzyme activity measurement.

The optical density of samples with unknown $\beta$-galactosidase activity consists in part of the optical density of nontransformed substrate. Optical density of the ONPG substrate without $\beta$-galactosidase was reduced with increased blood concentration of samples. This leads to reduced $\beta$-galactosidase activities compared to samples without blood contamination. Although the calculation of blood content was more exact due to steeper curve grades at $420 \mathrm{~nm}$ compared to those at $540 \mathrm{~nm}, \beta$-galactosidase activities as low as $1 \mathrm{mU}$ could not be detected. For determination of low $\beta$-galactosidase enzyme activities achieved in liposomal transfection experiments in vivo the ONPG substrate is therefore not suitable.

The use of the Galacton-Plus substrate was also compromised by blood contamination when the samples with known $\beta$-galactosidase content were studied. The measured luminescence was reduced up to $30 \%$ following addition of erythrocyte extract independent of erythrocyte extract concentration. Probably already a low concentration of erythrocyte extract led to saturation and diminished the luminescence measured. Comparison of values with different erythrocyte extract concentrations did not result in interpretable data. Measurements in the absence of the substrate were not possible as the lumines- cence results from the substrate itself. Therefore, negative controls with unknown blood amount cannot be included.

In the absence of reducing agent calculated $\beta$-galactosidase activities also depended on the time point of measurement following substrate addition to blood contaminating samples. The highest enzyme activities were found 30 min after substrate addition, which decreased progressively over time. The oxidation state of hemoglobin in samples without mercaptoethanol was time dependent and could lead to variable optical densities. Using mercaptoethanol, stabilization of light absorption in the samples was observed for at least $4 \mathrm{~h}$. The calculated $\beta$-galactosidase activities corresponded to those measured in samples without blood contamination. Therefore, reducing agent should still be added to blood-contaminated samples, prior to start analyzing.

Blood and endogenous $\beta$-galactosidase activity may variably contribute to the activity deriving from gene transfer in a range of $1-5 \mathrm{mU} / 100 \mu \mathrm{g}$ protein. Using alternative gene transfer systems with relatively high efficiency, such as adenoviral-mediated gene transfer, the transfer efficiency is usually lower than $8 \mathrm{mU} / 100 \mu \mathrm{g}$ protein $[8,9]$. Therefore, the error before correction for blood contamination represents more than $15 \%$ of the measured specific activity and can therefore significantly interfere with the results obtained.

Analyses of tissue extracts from various porcine organs demonstrated that arteries, heart tissue and lung tissue had relatively low endogenous $\beta$-galactosidase activity, of about $0.1 \mathrm{mU}$. In contrast, liver, kidney and intestinal tissue contained very high endogenous $\beta$-galactosidase enzyme activity, up to $5 \mathrm{mU}$. Reporter enzyme activities in transfected tissues should therefore additionally be corrected for the endogenous $\beta$-galactosidase activity found in nontransfected control tissue.

The accuracy of the method developed was confirmed in transfection experiments performed in vivo in a pig model. Uncorrected $\beta$-galactosidase enzyme activity demonstrated false-positive transfer efficiencies. In contrast, the $\beta$-galactosidase activities in transfected arteries corrected for blood content correlated well with results obtained by RT-PCR.

Knowledge of the major factors, which potentially could cause errors in the measurement of $\beta$-galactosidase enzyme activity, permits more accurate analysis of expression of this commonly used reporter gene. This procedure may be particularly helpful in the cardiovascular field, where usually low gene transfer rates and expression are achieved. 
In conclusion, this method represents a reliable technique for the evaluation of vascular in vitro and in vivo gene transfer experiments with the $\beta$-galactosidase reporter gene in the presence of blood, especially where low transfection efficiency may be expected.

\section{Acknowledgements}

This work was in part funded and J.P. is supported by the Deutsche Forschungsgemeinschaft (Ni 331/3-2) and Graduiertenkolleg for Vascular Biology (GRK 438). We wish to thank Dr. Tanya Huehns for proof-reading the manuscript.

\section{References}

1 Lim K, Chae CB: A simple assay for DNA transfection by incubation of the cells in culture dishes with substrates for beta-galactosidase. Biotechniques 1989;7:576-579.

2 Eustice DC, Feldman PA, Colberg Poley AM, Buckery RM, Neubauer RH: A sensitive method for the detection of beta-galactosidase in transfected mammalian cells. Biotechniques 1991;11:739-740.

3 Groth D, Keil O, Schneider M, Reszka R: Transfection assay for dual determination of toxicity and gene expression. Anal Biochem 1998;258:141-143.
4 Bronstein I, Fortin J, Stanley PE, Stewart GS, Kricka LJ: Chemiluminescent and bioluminescent reporter gene assays. Anal Biochem 1994; 219:169-181.

5 Fulton R, Van Ness B: Luminescent reporter gene assays for luciferase and beta-galactosidase using a liquid scintillation counter. Biotechniques 1993;14:762-763.

6 Nikol S, Huehns TY, Krausz E, Armeanu S, Engelmann MG, Winder D, Salmons B, Höfling B: Needle injection catheter delivery of the gene for an antibacterial agent inhibits neointimal formation. Gene Ther 1999;6:737748 .
7 Groth D, Keil O, Lehmana C, Schneider M, Rudo M: Preparation and characterisation of a new lipospermine for gene delivery into various cells. Int J Pharm 1998;162:143-157.

8 Schulick AH, Newman KD, Virmani R, Dichek DA: In vivo gene transfer into injured carotid arteries: Optimization and evaluation of acute toxicity. Circulation 1995;91:24072414.

9 Toyoda K, Ooboshi H, Chu Y, Fasbender A, Davidson BL, Welsh MJ, Heistad DD: Cationic polymer and lipids enhance adenovirusmediated gene transfer to rabbit carotid artery. Stroke 1998;29:2181-2188. 